\title{
The Use of Design Thinking in a Global Information Technology Company
}

\author{
Gabriel Kryvoruchca ${ }^{1}$, Lauriane Correa ${ }^{1}$, Rafael Parizi $^{1}$, Sabrina Marczak ${ }^{1}$ \\ ${ }^{1}$ MunDDoS Research Group - School of Technology \\ Pontifícia Universidade Católica do Rio Grande do Sul - PUCRS \\ Porto Alegre, RS, Brazil \\ gabriel.kryvoruchcalacad.pucrs.br \\ \{lauriane.pereira,rafael.parizi\}@edu.pucrs.br \\ sabrina.marczakepucrs.br
}

\begin{abstract}
Software companies have been using Design Thinking to support software development, fostering the creation of innovative features and products. However, there is not so much knowledge of what matters for the application of Design Thinking being successful. Thus, this study aims to describe how does the adoption of Design Thinking with software development take place in a global information technology company through an interview-based case study with 16 professionals. Our analysis indicates that Design Thinking is used in software products, software improvements, processes, user experience identification and solution discovery. Also, there are perceived benefits and challenges during the Design Thinking activities. As a result, this paper describes the Design Thinking phenomenon in software development, serving as a guide for practitioners on how to set up and implement Design Thinking activities and publishing more academic research.
\end{abstract}

\section{Introduction}

Information technology companies want to deliver software products in less time with higher-quality [Subih et al. 2019]. Putting the user at the center of the software development process has been pointed out for years as the key to success [Luedeke et al. 2018]. It has been argued that Design Thinking (DT) is relevant in this attempt to better establish user-centric activities to support the understanding of user needs and to develop a fit solution [Hehn et al. 2020].

The use of DT to aid software development activities fosters the development of human-centered solutions more effectively and, therefore, it is important to know in-depth about how organizations have used DT for their activities [Hehn and Uebernickel 2018].

This way, we focused on describing this phenomenon, answering the following research questions (RQ) "RQ1. How does the adoption of Design Thinking with software development take place?" and "RQ2. What are the perceived benefits and challenges of Design Thinking adoption?". It aims to identify how the adoption of Design Thinking with software development takes place in a global information technology company (called ORG - confidential name), located in Brazil.

Thus, this study conducted an interview-based case study with 10 coaches and 6 participants, totaling 16 professionals to understand how DT is used, what techniques and 
tools are used, how knowledge is shared to the team, which professionals (or team roles) get involved in Design Thinking activities and the perceived benefits and challenges of Design Thinking usage.

This paper reports a case study in a global information technology company. Our main contributions are: (i) a set of characteristics and techniques used in this context; (ii) perceived benefits by the teams; (iii) perceived challenges by the teams so far; and compared studies highlighting similarities and differences.

The paper is organized as follows: Section 2 presents the Design Thinking background. Section 3 provides the research method used. Section 4 describes the preliminary results. Section 5 discusses our findings. Section 6 covers related work. Section 7 concludes with a summary of this article and future studies.

\section{Design Thinking in Software Development}

Design thinking has gained recognition as an approach to problem-solving that relies on interdisciplinary teamwork, exploration of human needs, rapid prototyping and interactive learning cycles in the earlier stages of product, service and system development processes [Brown 2008]. Design thinking proposes to assist software development by supporting the understanding of the users needs [Vetterli et al. 2013].

Focusing on user needs, the purpose of DT is to collaboratively and innovatively identify opportunities to solve problems. It can be defined in three perspectives: as a process, as a mindset or as a toolbox [Brenner et al. 2016]. As a mindset, DT is focused on a strong orientation to discover the obvious and hidden customers' and users' needs and prototype the possible solutions. As a process, DT is seen as a combination of a micro-process as an innovation process and a macro-process as the milestones manifested in prototypes that must fulfill defined requirements. Finally, as a toolbox, DT refers to the application of numerous methods and techniques from design, software engineering and psychology [Brenner et al. 2016], for instance, personas, brainstorming, others.

DT and requirements engineering are distinct when it comes to the underlying philosophies, but many artifacts are complementary or even overlapping, the Design Thinking follows a philosophy of domain understanding and the learning curve leading to it - regardless of the surrounding processes [Hehn et al. 2020]. When looking through the lens of process, DT can be defined as a set of distinct working spaces, which can be adapted and executed non-sequentially according to the context [Thoring et al. 2011].

There is a wide variety of Design Thinking models, emerging and being updated to support the distinct contexts and problems that Design Thinking can support [HassoPlattner Institute 2020]. There are models such as double diamond design model [Council] 2020] and d-school model of the Hasso-Plattner-Institute [Hasso-Plattner Institute 2020]. Although exists the guides and manuals on Design Thinking, there are professionals who do not know how to conduct and decide techniques [Mateusz Dolata 2017].

\section{Research Method}

This study conducted an interview-based case study. We did design our study considering its qualitative nature [Dybå et al. 2011] based on the procedure by [Runeson and Höst 2009], which is: to establish the study goal and scope, to define the case and criteria to 
Table 1. Professionals' Profiles

\begin{tabular}{lllcc}
\hline ID & Role & Description & $\begin{array}{c}\text { Yrs } \\
\text { at } \\
\text { ORG }\end{array}$ & $\begin{array}{c}\text { Yrs } \\
\text { in }\end{array}$ \\
\hline C1 & Developer & Development team member & 10 & 5 \\
C2 & Developer & Development team member & 9 & 2 \\
C3 & Developer & Development team member & 8 & 3 \\
C4 & Developer & Development team member & 6 & 1 \\
C5 & Product Support Manager & Manages the entire product support organization & 10 & 7 \\
C6 & Partner Service Delivery & Responsible to provide support, training and assistance to & 10 & 6 \\
& & certified partners & & \\
C7 & Customer Relations & Responsible for representing the customer within ORG. & 9 & 5 \\
& & Will coordinate and speed up trainings, assistance, etc & & \\
C8 & Customer Center & Responsible for offering ORG applications and enabling & 7 & 4 \\
& & co-innovation with partners and customers & & \\
C9 & Product Support & Support engineer working with ORG applications & 5 & 2 \\
C10Product Support & Support team member & 5 & 4 \\
\hline P1 & Product Support & Support team member & 10 & 4 \\
P2 & Product Support & Support team member & 7 & 2 \\
P3 & Product Support & Support team member & 7 & 3 \\
P4 & Product Support & Support team member & 5 & 2 \\
P5 & Product Support & Support team member & 4 & 3 \\
P6 & Product Support & Support team member & 3 & 3 \\
\hline
\end{tabular}

select it, to select the data collection method, to decide on the data analysis method, and to get ethics approval to conduct the study within our institution and from the company management. Our research within this study was guided by the following research questions (RQ) "RQ1. How does the adoption of Design Thinking with software development take place?" and "RQ2. What are the perceived benefits and challenges of Design Thinking adoption?”.

\subsection{Case Study Setup}

We set up a descriptive case study in a global information technology company, called ORG. ORG develops and sells software systems solutions. This European-based company counts with over 10,000 information technology professionals around the world. Also, ORG follows D-school model in DT.

First, we observed a DT session for 2 hours to understand how it was applied. After that, we invited 20 employees from different teams, which 16 accepted to participate in this study. These professionals have different roles, such as Developer, Product Support, Manager and others, they are identified in Table 1.

We conducted an interview-based case study with 10 coaches and 6 participants, totaling 16 information technology professionals located in Brazil site. ORG classifies the professionals in two profiles: Design Thinking coach who receives a formal training and conducts sessions and, Design Thinking participant, who attends a session. A Design Thinking session can be organized in a few hours or a set of days, depending on demand. 
Table 2. Interview Script

\begin{tabular}{rll}
\hline RQ & ID & Question \\
\hline & Q1 & When, how and for what purpose is used Design Thinking? \\
RQ1 & Q2 & Who are the stakeholders involved during the Design Thinking? \\
Q3 & Which resources and tools do you use to support the Design Thinking? \\
Q4 & How the gathered knowledge during Design Thinking is shared to the development team? \\
\hline & Q5 & What are the perceived benefits of Design Thinking usage? \\
RQ2 & Q6 & What are the perceived challenges of Design Thinking usage? \\
& Q7 & What the perceived quality aspects are identified when Design Thinking is used? \\
\hline
\end{tabular}

\subsection{Data Collection and Analysis Methods}

The interviews were semi-structured, organized in 7 open-ended questions, see Table 2. To define this interview script we followed the guidelines suggested by [Kitchenham and Pfleeger 2002]. We performed the activities: (1) interview script creation, (2) script evaluation with a senior researcher who has industry experience in software development (12 years) and Design Thinking (3 years), (3) professionals selection, (4) interviews conduction, (5) interview transcription, and (6) data analysis and consolidation.

All professionals accepted the consent form. Each interview took on average of one-hour long. Notes were taken by the interviewer and used to aid data analysis. The study used content analysis technique to gain insights into the different variations of the Design Thinking phenomenon in a specific scenario through the subjects' feelings and thoughts. This way, all interviews were transcribed and analyzed using the this technique based on Krippendorff [Krippendorff 2018].

It aims to reveal perspective and patterns of behaviors among the professionals. All answers were analyzed to classify the results. The results were organized following the interview script. The authors discussed the results classification and categorization, achieving a consensus of all perspectives, as reported in Section 4

\section{Results}

In this section, we present the questions from our interview script and its consolidation based on professionals' perspectives. They are identified in Table 1 , where ' $\mathrm{C}$ ' represents a DT coach and 'P' a DT participant. Table 3 and Table 4 show an extract of the results for the interviews questions, grouped for RQ1 and RQ2, respectively.

The Design Thinking model used at ORG is D-school [Hasso-Plattner Institute 2020]: understand working space aims to discover the user needs, the professionals highlighted the following techniques: (i) briefing to start the conversation among all stakeholders; (ii) statement/challenge to explore the needs; (iii) customer journey map to understand the process as a whole; (iv) charting to define possible solutions, and; (v) creative reframe to rewrite the challenge, focused on discovering new aspects.

In the observe working space, they mentioned the ways: (i) interviews with users; (ii) shadowing to observe the users in their activities; (iii) desk research to explore about the topic, and; (iv) competitors' research to explore how the competitor are doing it. In point of view working space, the professionals mentioned the following techniques: (i) storytelling to describe users' perspectives; (ii) personas to identify the people who will 
Table 3. Interview's questions and professionals' answers for RQ1.

\begin{tabular}{|c|c|}
\hline \multicolumn{2}{|c|}{ RQ1. How does the adoption of Design Thinking with software development take place? } \\
\hline Question & Result (Professionals - ['C': Coach - 'P': Participant]) \\
\hline $\begin{array}{l}\text { Q1. When, how and for what purpose } \\
\text { is used Design Thinking? }\end{array}$ & $\begin{array}{l}\text { (i) discover new requirements }(\mathrm{C} 1, \mathrm{C} 2, \mathrm{C} 5, \mathrm{C} 6, \mathrm{P} 2) \\
\text { (ii) promote technological development }(\mathrm{C} 8, \mathrm{C} 9, \mathrm{P} 1, \mathrm{P} 4, \mathrm{P} 5) \\
\text { (iii) improve projects and processes }(\mathrm{P} 3, \mathrm{P} 4, \mathrm{P} 5, \mathrm{P} 6, \mathrm{C} 8) \text {, and } \\
\text { (iv) build a mindset }(\mathrm{C} 4, \mathrm{C} 5, \mathrm{C} 8, \mathrm{P} 2)\end{array}$ \\
\hline $\begin{array}{l}\text { Q2. Who were the stakeholders in- } \\
\text { volved during the Design Thinking? }\end{array}$ & $\begin{array}{l}\text { (i) interdisciplinary team (e.g. C9, C10, P1, P2, P3) } \\
\text { (ii) consultants (C1) } \\
\text { (iii) business specialists (C3, C6) } \\
\text { (iv) product owner }(\mathrm{C} 5, \mathrm{C} 10) \\
\text { (v) designers }(\mathrm{C} 2, \mathrm{C} 3, \mathrm{C} 7) \\
\text { (vi) managers }(\mathrm{C} 1, \mathrm{C} 7, \mathrm{C} 9, \mathrm{P} 6) \\
\text { (vii) end-users }(\mathrm{C} 4, \mathrm{C} 5, \mathrm{P} 2, \mathrm{P} 3) \\
\text { (viii) developers }(\mathrm{C} 1, \mathrm{C} 5, \mathrm{C} 8, \mathrm{C} 9, \mathrm{C} 10) \text {, and } \\
\text { (ix) Design Thinking coaches(P5, P6) }\end{array}$ \\
\hline $\begin{array}{l}\text { Q3. Which resources and tools did you } \\
\text { use to support the Design Thinking? }\end{array}$ & $\begin{array}{l}\text { (i) google drive (C5) } \\
\text { (ii) github (P4) } \\
\text { (iii) boards }(\mathrm{C} 3, \mathrm{C} 8, \mathrm{P} 1, \mathrm{P} 3, \mathrm{P} 4) \\
\text { (iv) prototyping tool (C2, C10), and } \\
\text { (v) flip-charts and pens }(\mathrm{C} 1, \mathrm{C} 5, \mathrm{C} 10 \text { e P1) }\end{array}$ \\
\hline $\begin{array}{l}\text { Q4. How the gathered knowledge dur- } \\
\text { ing Design Thinking was shared to the } \\
\text { development team? }\end{array}$ & $\begin{array}{l}\text { (i) storyboard (C6) } \\
\text { (ii) storytelling (C5, C6, C8) } \\
\text { (iii) pictures (e.g. C9, C10, P4, P5, P6) } \\
\text { (iv) sheets (C2, C8, P6) } \\
\text { (iv) documents (C2, C8, C9), and } \\
\text { (v) emails }(\mathrm{C} 7, \mathrm{C} 9, \mathrm{C} 10)\end{array}$ \\
\hline
\end{tabular}

interact with the solution, and; (iii) point of vien ${ }^{1}$ to represent the users' visions.

During the ideate working space, the professionals described the following techniques: (i) brainstorming to generate the participants' insights (ii) $2 \times 2$ matrix to organize insights; (iii) reverse brainstorming to find a viable solution. In prototype working space, the professionals mentioned the following techniques: (i) storyboard to align the ideas in a graphical visualization way; (ii) low-fidelity prototypes to evaluate the solutions; (iii) canvas to visualize the business aspects (iv) flowchart to draw the flows; (iv) mock-ups to give an idea of how it would be and then start a prototype, and; (v) physical prototypes.

In test working space, the professionals reported the (i) test matrix to map the positive and negative points, and questions about the solution; (ii) user validation using paper prototype; (iii) usability tests, and; (iv) user feedback to understand the users' perceptions.

\section{Discussion}

This study identifies how the adoption of Design Thinking with software development takes place in a global information technology company. Our discussion is organized to answer our two research questions.

\footnotetext{
${ }^{1}$ Apache MADlib: https://madlib.apache.org/
} 
Table 4. Interview's questions and professionals' answers for RQ2.

\begin{tabular}{ll}
\hline \multicolumn{2}{c}{ RQ2. What are the perceived benefits and challenges of Design Thinking adoption? } \\
\hline Question & Result (Professionals)- ['C': Coach - 'P': Participant]) \\
\hline $\begin{array}{l}\text { Q5. What were the perceived } \\
\text { benefits of DT usage? }\end{array}$ & $\begin{array}{l}\text { (i) creativity (P1, P4) } \\
\text { (ii) discovery of innovative solutions (C4, C10, P3) } \\
\text { (iii) cost reduction and time optimization (C3, C6, C8) } \\
\text { (iv) users' collaboration (C2, C3, C6, C8, P6) } \\
\text { (v) focus on end users (C3, C5, C9, P2, P5) and } \\
\text { (vi) problem identification (C1, C2, C4, C5, P1, P2) }\end{array}$ \\
\hline $\begin{array}{l}\text { Q6. What were the perceived } \\
\text { challenges of DT usage? }\end{array}$ & $\begin{array}{l}\text { (i) availability of rooms (P1, P2, C7) } \\
\text { (ii) lack of valorization (C1, C10, P1, P5) } \\
\text { (iv) lack of goals' definitions (P5, C10) }\end{array}$ \\
\hline Q7. What the perceived quality & (i) effort maintenance reduction (C5) \\
aspects are identified when DT $1, \mathrm{C} 5, \mathrm{P} 6)$, and \\
is used?
\end{tabular}

\section{RQ1. How does the adoption of DT with software development take place?}

Through our case study, we observed that period of time to use Design Thinking depends on the goal, e.g. a Design Thinking can take months or hours. The participants use it to focus on solving problems, improving solutions or building a mindset among participants. The interpretation of Design Thinking as a mindset and as a process were dominant in coaches' and participants' perceptions. This is in line with research that claims that practicing Design Thinking can lead to the development of a Design Thinking mindset [Brenner et al. 2016].

The professionals reported that Design Thinking was essential to achieve specific project goals, through working spaces with tools and techniques to achieve and explore these goals. We found that Design Thinking, using d-school model, is applied in different ways with software development, showing that there is indeed a need for different levels of Design Thinking application within the software development process. Existing studies suggest that the level of Design Thinking application depends on the project's goal, e.g. [Dobrigkeit et al. 2019].

Additionally, we identified that Design Thinking has a strong focus on understanding the users. Thus, the participants need to work in interdisciplinary teams and explore problems and solutions, matching with the Design Thinking principles mentioned within the literature [Brenner et al. 2016, Brown 2009, Díaz et al. 2014].

Luedeke et al. [Luedeke et al. 2018] argue that deploying the appropriate methods during Design Thinking is a key success factor. All participants of this study use the D-school model, however, each coach uses techniques to achieve the specific goal.

Overall, the participant roles and their understanding of Design Thinking suggests that different roles can conduct Design Thinking, but it is important to consider the experience or good knowledge of the Design Thinking coach. Because of it, the company gives the training to empower the professional to conduct Design Thinking sessions, 
called Design Thinking coach. Also, our findings highlight the importance of transfer the knowledge gathered during the Design Thinking among all involved.

\section{RQ2. What are the perceived benefits and challenges of Design Thinking adoption?}

Our findings suggest that Design Thinking is a good way to identify the users' and clients' needs, exploring it in depth and developing products focusing on their needs. It can be observed the relationship between participants who have a Design Thinking mindset and implementation of it. We identified that the coaches not only use Design Thinking to improve their software products but also to improve their processes or working spaces.

The perceived benefits were the cost reduction and time optimization because the participants are engaged to build a solution together, so it increases the quality during solution definition. Also, the users' collaboration to discover and gather software requirements, reducing conflicts between people. It confirms that Design Thinking adds value to deliverable solving practical problems, as mentioned in literature [Brown 2008].

Our findings indicate that DT reflects the needs in designed solutions, promoting satisfaction between stakeholders. However, our findings suggest some challenges such as unavailability of rooms to conduct Design Thinking for an extended period of time, coaches unavailability to conduct sessions and enough time to solve the problem.

\section{Related Work}

Studies are discussing how to use Design Thinking in software development, they focus on understanding an issue or phenomenon, illustrated in Table 5. In our study, we conducted a case study to explore the Design Thinking adoption and the perceived benefits and challenges in a global software company.

Carlgren, Elmquist and Rauth [Carlgren et al. 2014] (column A) argued that Design Thinking can be understood as a user-centered innovation approach, a process to develop new ideas, a mindset, or a combination of mindset and methods. In line with these findings, we identified this understanding among our professionals.

Hehn and Uebernickel [Hehn and Uebernickel 2018] (column B) highlighted the integration among stakeholders, better usability requirements elicitation and different viewpoints shared for an in-depth requirements elicitation during Design Thinking [Hehn and Uebernickel 2018]. Also, Lucena et al. [Lucena et al. 2016] (column C) identified that time spent contributes to improve software development goals and deliver better results and Jensen, Lozano and Steinert [Jensen et al. 2016] (column D) observed that Design Thinking involves the customer on the products' context understanding [Jensen et al. 2016]. De Paula, Amancio and Flores [de Paula et al. 2020] (column E) identified that Design Thinking adds value to the product, project, people and whole organization.

In our study (column F), we identified the same characteristics mentioned above and cost reduction because the stakeholders are engaged during the Design Thinking. De Paula, Amancio and Flores highlighted the known solutions emerged and many ideas generated were executed as challenges de Paula et al. 2020]. Our findings suggest that innovative solutions can emerge during the DT, however, some ideas are not executed too. 
Table 5. Related work

\begin{tabular}{|c|c|c|c|c|c|c|}
\hline & $\begin{array}{l}\text { A) Carlgren, } \\
\text { EImquist } \\
\text { and Rauth }\end{array}$ & $\begin{array}{l}\text { B) Hehn and } \\
\text { Uebernickel }\end{array}$ & $\begin{array}{l}\text { C) Lucena } \\
\text { et al. }\end{array}$ & $\begin{array}{l}\text { D) Jensen, } \\
\text { Lozano and } \\
\text { Steinert }\end{array}$ & $\begin{array}{l}\text { E) de Paula, } \\
\text { Amancio and } \\
\text { Flores }\end{array}$ & F) Our Study \\
\hline Objective & $\begin{array}{l}\text { Explored how } \\
\text { DT is used in } \\
\text { large organi- } \\
\text { zations }\end{array}$ & $\begin{array}{l}\text { Identified the } \\
\text { potential be- } \\
\text { tween DT and } \\
\text { Requirements } \\
\text { Engineering }\end{array}$ & $\begin{array}{l}\text { Identified } \\
\text { how IBM } \\
\text { uses DT }\end{array}$ & $\begin{array}{l}\text { Described the } \\
\text { research fields } \\
\text { behind the DT } \\
\text { methods }\end{array}$ & $\begin{array}{l}\text { Evaluated } \\
\text { a DT light } \\
\text { version usage } \\
\text { at IBM }\end{array}$ & $\begin{array}{l}\text { Describes the } \\
\text { adoption of } \\
\text { DT in a global } \\
\text { IT company }\end{array}$ \\
\hline Method & $\begin{array}{l}\text { Interviews } \\
\text { with partici- } \\
\text { pants from } 16 \\
\text { companies }\end{array}$ & Case study & Survey & $\begin{array}{lr}\text { Case } & \text { study } \\
\text { with profes- } \\
\text { sionals from } \\
\text { SAP }\end{array}$ & $\begin{array}{l}\text { Survey with } \\
\text { two groups } \\
\text { from IBM }\end{array}$ & $\begin{array}{l}\text { Case study } \\
\text { with } 16 \text { pro- } \\
\text { fessionals } \\
\text { from a global } \\
\text { IT company }\end{array}$ \\
\hline $\begin{array}{c}\text { RQ1. } \\
\text { Adoption }\end{array}$ & $\begin{array}{l}\text { DT as a } \\
\text { user-centered } \\
\text { approach, } \\
\text { a process } \\
\text { to develop } \\
\text { new ideas, a } \\
\text { mindset, or a } \\
\text { combination } \\
\text { of mindset } \\
\text { and methods }\end{array}$ & $\mathrm{n} / \mathrm{a}$ & $\begin{array}{l}\text { DT is used } \\
\text { for product } \\
\text { develop- } \\
\text { ment }\end{array}$ & $\begin{array}{lr}71 \% & \text { use } \\
\text { Scrum with } \\
\text { DT and } & 14 \% \\
\text { Kanban } & \end{array}$ & $\mathrm{n} / \mathrm{a}$ & $\begin{array}{l}\text { DT is used } \\
\text { in software } \\
\text { products, } \\
\text { software im- } \\
\text { provements, } \\
\text { processes, } \\
\text { user ex- } \\
\text { perience } \\
\text { identification } \\
\text { and solution } \\
\text { discovery }\end{array}$ \\
\hline $\begin{array}{c}\text { RQ2. } \\
\text { Perceived } \\
\text { benefits }\end{array}$ & $\mathrm{n} / \mathrm{a}$ & $\begin{array}{l}\text { Integration } \\
\text { among stake- } \\
\text { holders, better } \\
\text { usability re- } \\
\text { quirements } \\
\text { elicitation } \\
\text { and different } \\
\text { viewpoints } \\
\text { shared for } \\
\text { an in-depth } \\
\text { requirements } \\
\text { elicitation }\end{array}$ & $\begin{array}{l}\text { The time } \\
\text { spent con- } \\
\text { tributes to } \\
\text { improve ag- } \\
\text { ile software } \\
\text { develop- } \\
\text { ment goals } \\
\text { and deliver } \\
\text { better results }\end{array}$ & $\begin{array}{l}\text { Provide an } \\
\text { interactive } \\
\text { development } \\
\text { with stake- } \\
\text { holders, gain } \\
\text { a holistic } \\
\text { problem } \\
\text { overview and } \\
\text { involve the } \\
\text { customer on } \\
\text { the prod- } \\
\text { ucts' context } \\
\text { understanding }\end{array}$ & $\begin{array}{l}\text { DT adds value } \\
\text { to the product, } \\
\text { project, peo- } \\
\text { ple and whole } \\
\text { organization. }\end{array}$ & $\begin{array}{l}\text { Cost reduc- } \\
\text { tion, time } \\
\text { optimization, } \\
\text { users col- } \\
\text { laboration } \\
\text { to discover } \\
\text { and gather } \\
\text { the software } \\
\text { requirements, } \\
\text { conflicts re- } \\
\text { duction and } \\
\text { increased } \\
\text { quality }\end{array}$ \\
\hline $\begin{array}{c}\text { RQ2. } \\
\text { Perceived } \\
\text { chal- } \\
\text { lenges }\end{array}$ & $\mathrm{n} / \mathrm{a}$ & $\mathrm{n} / \mathrm{a}$ & $\mathrm{n} / \mathrm{a}$ & $\mathrm{n} / \mathrm{a}$ & $\begin{array}{l}\text { Participants } \\
\text { used already } \\
\text { known so- } \\
\text { lutions and } \\
\text { many of the } \\
\text { ideas gener- } \\
\text { ated were not } \\
\text { executed }\end{array}$ & $\begin{array}{l}\text { Unavailability } \\
\text { of rooms to } \\
\text { use during } \\
\text { DT, coaches } \\
\text { unavailable to } \\
\text { conduct DT } \\
\text { and enough } \\
\text { time to solve } \\
\text { the problem }\end{array}$ \\
\hline
\end{tabular}

\section{Final Considerations}

This study aims to describe how the adoption of DT with software development takes place in global information technology. This way, we identified how DT, through working spaces, is used, what techniques and tools are used, which artifacts are produced and which professionals (or team roles) get involved in DT activities. Also, we identified the perceived benefits and challenges of DT usage. With these parameters in mind, we conducted semi-structured interviews with 10 coaches and 6 participants, totaling 16 
professionals who have experience with DT in software development.

Our findings can serve as a guide for practitioners on how to set up and implement DT activities. Thus, we focus on answering the research questions (RQ) "RQ1. How does the adoption of DT with software development take place?" and "RQ2. What are the perceived benefits and challenges of DT adoption?".

As a result, we identified that DT is used in software products, software improvements, processes, user experience identification and solution discovery. Also, there are perceived benefits like cost reduction, time optimization, users' collaboration to discover and gather the software requirements, conflict reductions and increased quality. However, there are challenges such as unavailability of rooms to use during DT, coaches unavailable to conduct DT and enough time to solve the problem.

The study has limitations inherent to any empirical study. For instance, we interviewed only 16 employees, which might not represent the company view on the topic. To mitigate that we did select employees with different levels of expertise, time working in the company, and from different company areas.

For future studies, we intend to explore in-depth knowledge about DT and its tools, and techniques used in software development, as well as conduct case studies with other software companies to create a wider vision of DT integrated to software process, its benefits, challenges and ways of the application.

\section{Acknowledgements}

This study was partially financed by the Coordenação de Aperfeiçoamento de Pessoal de Nível Superior - Brasil (CAPES) - Código de Financiamento 001.

\section{References}

Brenner, W., Uebernickel, F., and Abrell, T. (2016). Design Thinking as Mindset, Process, and Toolbox. In Design Thinking for Innovation: Research and Practice, pages 3-21. Springer.

Brown, T. (2008). Design Thinking. Harvard Business Review, 86:84-92.

Brown, T. (2009). Change by Design: How Design Thinking Transforms Organizations and Inspires Innovation. page 272. HarperCollins, New York, United States.

Carlgren, L., Elmqvist, M., and Rauth, I. (2014). Exploring the use of Design Thinking in Large Organizations: Towards a Research Agenda. Swedish Design Research Journal, 11:55-63.

Council, D. (1944 (accessed October 10, 2020)). The Design Process: What is the Double Diamond? Available in: http://designcouncil.org.uk/.

de Paula, T. R., Amancio, T. S., and Flores, J. N. (2020). Design Thinking in Industry. IEEE Software, 37(02):49-51.

Dobrigkeit, F., de Paula, D., and Uflacker, M. (2019). InnoDev: A Software Development Methodology Integrating Design Thinking, Scrum and Lean Startup. In Design Thinking Research, pages 199-227. Springer. 
Dybå, T., Prikladnicki, R., Rönkkö, K., Seaman, C., and Sillito, J. (2011). Qualitative Research in Software Engineering. Empirical Software Engineering, 16(4):425-429.

Díaz, P., Aedo, I., and Cubas, J. (2014). CoDICE: Balancing Software Engineering and Creativity in the Co-Design of Digital Encounters with Cultural Heritage. In Proceedings of the Workshop on Advanced Visual Interfaces, pages 253-256, Como, Italy. ACM.

Hasso-Plattner Institute ((accessed October 10, 2020)). What is Design Thinking? Available in: https://hpi-academy.de/en/design-thinking/what-is-design-thinking.html.

Hehn, J., Mendez, D., Uebernickel, F., Brenner, W., and Broy, M. (2020). On Integrating Design Thinking for Human-Centered Requirements Engineering. IEEE Software, 37(2):25-31.

Hehn, J. and Uebernickel, F. (2018). The Use of Design Thinking for Requirements Engineering: An Ongoing Case Study in the Field of Innovative Software-Intensive Systems. In Proc. of the Int'l Requirements Eng. Conf., pages 400-405, Banff, Canada. IEEE.

Jensen, M. B., Lozano, F., and Steinert, M. (2016). The Origins of Design Thinking and the Relevance in Software Innovation. In Procedings of the Conference on ProductFocused Software Process Improvement, pages 675-678, Trondheim, Norway. Springer.

Kitchenham, B. and Pfleeger, S. L. (2002). Principles of Survey Research Part 4: Questionnaire Evaluation. SIGSOFT Software Engineering Notes, pages 20-23.

Krippendorff, K. (2018). Content Analysis: An Introduction to Its Methodology. Sage, New York, United States.

Lucena, P., Braz, A., Chicoria, A., and Tizzei, L. (2016). IBM Design Thinking Software Development Framework. In Proceedings of the Brazilian Workshop on Agile Methods, pages 98-109, Curitiba, Brazil. Springer.

Luedeke, T., Köhler, C., Conrad, J., Grashiller, M., Sailer, A., and Vielhaber, M. (2018). Cyber-Physical Systems/Property-Driven Design in the context of Design Thinking and Agile Development of Cyber-Physical Systems: Use Cases and Methodology. In Proceedings of the NordDesign Conference, pages 1-24, Linköping, Sweden.

Mateusz Dolata, Falk Uebernickel, G. S. (2017). The power of words: Towards a methodology for progress monitoring in design thinking projects. In International Conference on Wirtschaftsinformatik, pages 1190-1204, St. Gallen, Switzerland.

Runeson, P. and Höst, M. (2009). Guidelines for Conducting and Reporting Case Study Research in Software Engineering. Empirical software engineering, 14(2):131.

Subih, M. A., Malik, B. H., Mazhar, I., Yousaf, A., Sabir, M. U., Wakeel, T., Izaz-ul Hassan, W. A., Bilal-bin Ijaz, M. S., and Nawaz11, H. (2019). Comparison of Agile Method and Scrum Method with Software Quality Affecting Factors. International Journal of Advanced Computer Science and Applications, 10(5):531-535.

Thoring, K., Müller, R. M., et al. (2011). Understanding Design Thinking: A Process Model Based on Method Engineering. In Proc. of the Int. Conference on Engineering and Product Design Education, pages 493-498, London, UK. Design Society.

Vetterli, C., Brenner, W., Uebernickel, F., and Petrie, C. (2013). From Palaces to Yurts: Why Requirements Engineering Needs Design Thinking. IEEE Internet Computing, pages 91-94. 